\title{
Economic Basis of Digital Banking Services Produced by FinTech Company in Smart City
}

\author{
Yelena Popova \\ Transport and Telecommunication Institute, Riga, Latvia
}

Received: 16 June 2021. Revision received: 22 July 2021. Accepted: 26 August 2021

\begin{abstract}
The accelerated urbanization rate results in the birth of the Smart City concept, presupposing the more efficient use of digital technologies for the benefit of inhabitants and businesses. The idea of digital banking is one of the key issues in a smart city concept. The research should demonstrate that the efficient and effective way to produce such kind of services is to use the fintech companies' facilities. Many researchers study fintech from a technological point of view, the contribution of fintech to general banking, the level of satisfaction of customers with fintech products. However, there is a gap in studying the economic basis of these companies. The research aims to determine the economic basis for the projects implemented by the fintech company and to determine the source of the efficiency of these companies in financial operations compared to the conventional bank. It has additional importance since the analysis of research devoted to technological solutions demonstrates a certain lacuna in the economic substantiation of such smart solutions. The results of this study are based on the implementation of traditional Cost-Benefit and Total Cost of Ownership analyses and include the developed cost and income functions, calculated Benefit/Cost ratio, and demonstrated the source of efficiency of fintech company compared to a traditional bank. Therefore, the activities of a fintech company in the area of digital banking received the economic ground, and this fact decreases the gap between intuitive comprehension of the necessity of the introduction of smart solutions in practice and the economic substantiation of this process.
\end{abstract}

Key Words: smart city, cost-benefit analysis, fintech company, digital banking, conventional bank.

\section{JEL Classification: O330; M29}

Reference: Popova, Y. (2021). Economic Basis of Digital Banking Services Produced by FinTech Company in Smart City. Journal of Tourism and Services, 23(12), 86-104. doi: 10.29036/jots.v12i23.275

\section{Introduction}

Life is changing each day, and these changes deepen the urbanization level. According to Kumar \& Dahiya (2017), the level of urban population will be up to $82 \%$ in Europe and $74.87 \%$ in the six biggest regions of the world by 2050 . This accelerated urbanization rate creates specific conditions for the development of the economy (Popova, 2020). However, the contemporary tendencies in the economy, ecology, social sphere put forward issues that have never been topical before. These issues result in numerous problems of organizing all the processes in the urban areas.

The global challenges gave birth to the concept of Smart City. A smart city is an attempt to solve the serious problems which the contemporary city faces; it is one of the most promising paradigms of urban development (Wataya \& Shaw, 2019; Zagulova and Popova, 2021). There are numerous definitions of smart city, but this paper is based on the definition by the European Commission, according to which a smart city is a place where traditional networks and services are made more efficient with the use of 


\section{JOURNAL OF TOURISM AND SERVICES}

Issue 23, volume 12, ISSN 1804-5650 (Online)

www.jots.cz

digital and telecommunication technologies for the benefit of its inhabitants and business (Lai et al., 2020; European Commission, 2014). Therefore, it consists of innovative activities based on the developments in the processes, plans, methods that new technologies cause (Ključnikov et al., 2019; Ključnikov, et al., 2021; Civelek et al., 2020a; Civelek et al., 2021a), including the changes in payment process such as mobile payments (Civelek et al., 2020b).

The definition mentioned above also supports the idea of Etezadzadeh (2016) that the main function of the city is to provide access to any benefit, good or service for the city inhabitants. In this regard, local digital currencies might be an example that provides economic and social benefits for city inhabitants (Ključnikov et al. 2020a; Ključnikov et al., 2020b; Civelek et al., 2019; Civelek et al., 2021b). The growth of the urban population requires ensuring access to all urban opportunities for the increased number of people, while many city departments are not supposed for servicing such a great amount of the population, though they must create a liveable and sustainable environment for its citizens (Wataya \& Shaw, 2019). Therefore, the pressure on all services of all cities all over the world increases - and only technologies are capable of overcoming the lack of traditional services (Dhar, 2016; Anthopoulos et al., 2019; Ardito et al., 2019; Serrano, 2018). As a result, smart technologies enter the everyday life of people and assist the process of efficient allocation of resources, involving "smart" solutions in all spheres of urban life. The research considers fintech companies as an alternative for some traditional operations of conventional banks and the readiness of smart cities for taking digital banking implemented by fintech companies.

Another important issue is to be able to estimate the costs and the benefits of smart solutions. According to Popova Y. (2020), very few researches comprise the comprehensive cost analysis, and this research is aimed at presenting the functions of costs and income for fintech companies operating in smart cities with smart solutions. For example, Abraham et al. (2019) write about decreased costs of service produced by fintech companies but does not provide any research of the cost structure of the company or the source of these decreased costs. Malaika M. (2021) mentions the low capital cost of a fintech company but does not show the reasons for the situation. There are researches, considering the structure of assets and costs of banks, CAPM model (Baker \& Wurgler, 2015), some of the obtained results can be attributed to fintech companies, but the economic basis of fintech company functioning is not presented. Moreover, the author has not found any studies of the costs and incomes of fintech companies, their peculiarities, and specificities. Therefore, it seems very important to determine them. The goal of the research is to determine the economic basis for the projects implemented by fintech companies, and determine the source of the efficiency of these companies in financial operations in comparison with the conventional bank, and to develop the costs and income functions for fintech companies. It can decrease the lacuna existing in the economic substantiation of smart solutions.

\section{Literature review}

\subsection{Financial sector of smart city}

The smart city employs digital technologies for better decision-making in all fields. These technological solutions are oriented to perfect the quality of life in the urban area and simultaneous economic efficiency (Dhar, 2016; IMD World Competitiveness Center, 2020; Ardito et al., 2019).

One of the most important functions of the smart city is providing the operations with money without any difficulties, delays and on the proper legal basis, which is based on using the proper digitalization level (Makarchenko et al., 2016; Dhar, 2016).

Circulation of cash flows is a very special segment of urban life. The urban area provides a higher velocity of this circulation since the basis of urban life services, which increase the velocity of money transactions. The great percentage of the population concentrated in cities contributes to the increased volume of 


\section{JOURNAL OF TOURISM AND SERVICES}

Issue 23, volume 12, ISSN 1804-5650 (Online)

www.jots.cz

various daily electronic payments in cities. (Makarchenko et al., 2016; Customer Loyalty in Retail Banking, 2014)

Therefore, the financial systems face the special challenges.

People trust in the internet technologies and mostly prefer online transactions. The number of internet banking users is increasing on the constant basis, and it is expected, this growth will continue (Salloum et al., 2019; Mehrad and Mohammadi, 2017; Abrol, 2016).

The digital banking systems meet many needs of smart city. It is assumed, these systems existing in the smart city represent an ordered set of rules, modern communication solutions and operations, which allow safe and efficient financial settlements and transfers between the individual participants. Among these individual participants can be either businesses, doesn't matter big or small ones, individuals, or government agencies (Alalwan et al., 2017; Al-Saedi et al., 2019; Barkhordari, 2017).

The financial sector should provide the speed of operation. Due to modern technologies the transactions become instant, whether it is paying for goods or services, booking tickets, or simply transferring money from account to account. The digital payments have become a constituent part of smart cities, since they are included in almost all services offered to the participants of smart city. In turn, these services, including procurement, labor compensation, consumption expenditures, tax collections, payments of government to citizens and businesses, and others represent the core of economic life of smart city (Etezadzadeh, 2016). In general, the financial sector within smart city has three very important tasks: to provide the smooth operation of all elements of the system; to ensure the security of transactions; and to insure against any failures in financial transactions (Kelemen et al. 2021). Digitalisation of the payment procedures within smart city can improve the effectiveness, efficiency and velocity of money transactions between all economic participants of smart city: people, businesses, governmental structures (Allen et al., 2020; Caballero-Morales et al., 2020).

Another important function of digital banking is to regulate the share of cash in all payments. Operations with cash provide additional costs for the national economy and also increase the risk of implementing the illegal criminal activities and tax avoidance (McAndrews, 2020; Rogoff \& Rogoff, 2017). The electronic banking systems appeared for solving such problems as reduction of costs of all operations with money, provision of the necessary level of flexibility of small purchases and instant payments, support of e-commerce and certainly it should provide an advance of the security of payments and create protection against any form of crime in this sphere (Francisco et al., 2015).

Another very important thing is legal regulation of this sector of smart city. Practically, financial sector is one of the most regulated segments of smart city, and must function and have all transactions, as well the rules and principles of operation according to the legal basis, and the regulation and control are usually provided by Central Bank (Rubio et al., 2020; Darolles, 2016, Agarwal et al, 2014; Granja et al, 2017; Buchak et al., 2018).

All these functions should be completed by digital banking system within smart city.

The modern banking system is based on the latest technologies, and it puts certain requirements towards the infrastructure of smart city. To stand the pressure of contemporary life, the traditional financial institutions have to cooperate with fintech companies.

\subsection{Fintech Companies}

The contemporary tendencies have accelerated the transformation processes within financial sphere, and also highlighted the systemic problems of the financial world. However, the majority of these issues cannot be solved by traditional ways, and the traditional financial institutions switch to new innovative solutions, and only this fact allows them surviving in this environment. One of these solutions is cooperation with innovation-focused fintech companies (Varga, 2017; Philippon, 2015).

Fintech companies are not newcomers in the financial markets, and smart cities implement quite successfully the opportunities, provided by these companies. Fintech, or financial technologies help 


\section{JOURNAL OF TOURISM AND SERVICES}

Issue 23, volume 12, ISSN 1804-5650 (Online)

www.jots.cz

financial services and companies manage the financial aspects of a business via software, applications, processes, and business models. This name can also be referred to an industry where companies use new financial technologies and solutions to compete with traditional financial organizations, using fintech tools (Klevets, 2021; Darolles, 2016).

Smart cities use fintech companies as a basis for their financial operations with great pleasure. The main reasons for this is their digital nature, more efficient cost structure, mobility, higher customer loyalty. Consumers get as a norm quick, easy, low-cost financial transactions, and use them widely (Asif et al., 2020). The fintech companies participate in almost all online transactions in smart city, from money transfers to utility payments (Dranev et al., 2019; Philippon, 2016).

For example, the customers can have direct exchange of money without participation of any intermediary via "Smart contracts" (Zheng et al., 2020); the insurance companies use InsurTech for optimising the procedures and processes (Cortis et al., 2019; Marano, 2019; Stoeckli et al., 2018).; the legal component is very urgent nowadays, when the countries and international financial institutions elaborate very strict standards for all participants of financial sphere, and the regulatory technologies RegTec are capable of providing the necessary level of compliance with legal acts ((Buchak et al., 2018; Granja et al, 2017). Fintech companies via Robo-advising software can work out the tips for investment activities, and these pieces of advice will be significantly cheaper for investors compared to the traditional consulting companies (Abraham et al., 2019; Gârleanu \& Pedersen, 2018); employment of artificial intellect solutions allow analysing the big data for management purposes (Cortis et al., 2019): artificial intellect can be used for examining the activities and results of international financial institution for organisational procedures. Special popularity nowadays belongs to non-banking services of fintech companies, which provide financial services to people who have low income; these people usually cannot receive financial credit services at traditional financial institutions (Buchak et al., 2018; Petralia et al., 2019). It is supposed that fintech companies are able to provide cybersecurity and defend the clients from cyber-attacks (Malaika, 2021). Mobile payments have become the traditional service which is actively used by customers (Allen et al., 2020); RPA (robotic process automation) is used quite widely: via the user interface, robots (bots) collect data and manage applications (Aguirre \& Rodriguez, 2017).

Conversational interfaces in the form of voice assistance and chatbots are also used very actively.

This short list does not include all the functions which are traditional for fintech companies. They also include, for example, stock-trading apps, crowdfunding, Cryptocurrency, digital currency, Blockchain technology, open banking, and others.

The achievements of fintech companies in smart cities are measured by Fin Tech Index (Findexable Limited, 2020). The Report analyses 238 smart cities all over the world. The Fin Tech hubs by region are presented in Graph 1.

Graph 1. Fin Tech hubs by region

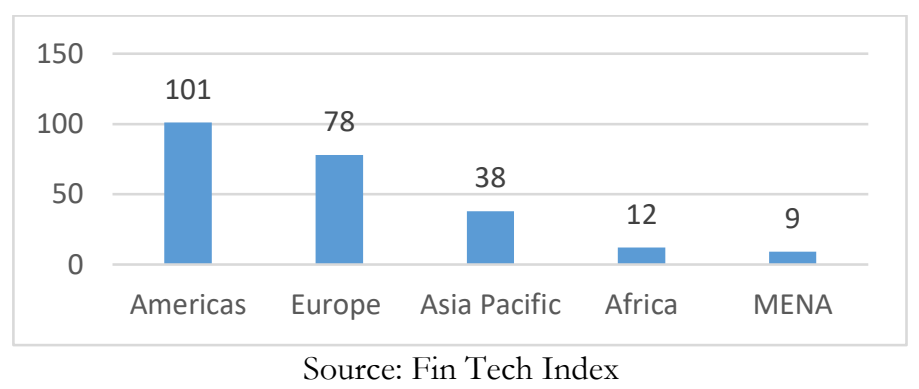

As it can be seen, Europe is in the second place after North and South American continents. 


\section{JOURNAL OF TOURISM AND SERVICES}

Issue 23, volume 12, ISSN 1804-5650 (Online)

www.jots.cz

The European countries got the new push of development due to the such driver as digitalization and technologies, which finds its prove in situation with the digital banking systems. Nevertheless, the digital banking has different basis in the European countries.

The developed European economies, achieving the prosperity before the era of the internet, have the infrastructure, which was automatically oriented on check and cash payments; therefore, these states faced the necessity to introduce the updated infrastructure which would be adequate for electronic payments. As a result, for the developed countries the first steps in the transformations of digital banking were connected with the technological and technical issues. Since these expenditures are very high, it is necessary for the banks to solve the problem of building the products on the top of the infrastructure, and these products should create the value to the customers, facilitate the war on cash, and facilitate the return of the investment as quickly as possible (Bansal et al., 2015).

The countries of Central and Eastern Europe started advancement of their modern economic relations simultaneously with the technological development. During rather short period of time these countries faced the necessity to become ready for using the digital banking. The new economic relations required new payment infrastructure. The new economic relations are closely interconnected with shifting numerous operations to the digital channels (Ozili, 2018; Kozak \& Golnik, 2020). The great contribution to the development of digital banking systems in these countries is made by the fintech companies which find there the wonderful field for their activities. Riga (Latvia) is gaining the position of smart city, and even nowadays it is included in general Top 100 smart cities in the world ( $96^{\text {th }}$ position) and takes high position (the $34^{\text {th }}$ place) in Europe (Findexable Limited, 2020).

\section{Methods}

The goal of the research is to determine the economic basis for the projects implemented by fintech company. One of the methods is Cost-benefit analysis (CBA). It comprises evaluation of the options, oriented on the achievement of the benefits, and their advantages and disadvantages. According to the International Records Management Trust, it is a systematic approach to estimating the strengths and weaknesses of the projects (IRMT, 2006)

Koopmans \& Mouter (2020), Mouter (2018), David et al. (2013), Ngulube (2011) and Báeza and Herrerob (2012) suppose, this technique is the best approach in terms of benefits in labor. It also can be used for estimating policy decisions and projects. The method of cost-benefit analysis presupposes the process of cash flows discounting, which allows making the calculations more accurate and reliable. In case the project lasts longer than a year all the cash flows should be discounted, and the weighted average cost of the capital (WACC), involved in the project implementation, can serve as a discount rate.

Another method used for estimating the projects is Total Cost of Ownership (TCO) method. TCO allows estimating the costs of projects (Bataev et al., 2020; Medina-Borja, 2017; Zhilenkova et al, 2017). TCO can be incorporated in the financial benefit analysis, it specifies the total economic value of the project basing on the total costs of acquisition and operating costs.

This research employs the standard TCO function for the costs; however, the time component is also included since CBA method uses discounted cash flows. Practically, it is the calculation of the traditional Net Present Value of the project; the author has determined the cash flows corresponding to the considered project: $B$ is the flow of benefits (in this case, revenues received by fintech company in the process of implementing the project) and $C$ is a flow of costs, appeared in the project, and $r$ is a discount rate applied to cash flows in time (as it has been mentioned above, the weighted average cost of the capital (WACC), involved in the project implementation, can serve as a discount rate). 


$$
N P V=\sum_{t=0}^{\infty}\left(\frac{B_{t}-C_{t}}{(1+r)^{t}}\right)
$$

The list of costs and the list of incomes of fintech company are done on the basis of estimations of the head of fintech company Starbridge Ltd.; according to the interview these costs and incomes can be considered as common for the fintech companies (with minor deviations), but not unique for Starbridge Ltd. only.

There was calculated the Cost-Benefit Ratio for one of the projects of the company. The flows of costs and benefits were estimated according to the elaborated costs and benefits functions. This ratio practically can be used for estimating the future projects in the process of their budgeting; however, applied to the implemented projects, it allows estimating the obtained results.

One of the objectives of the research is to determine the source of efficiency of fintech company in the process of producing digital banking services, compared to the conventional bank. It was decided to compare the structure of financial statements of fintech company and traditional bank, operating in the Baltic States. Certainly, the difference in the number and scope of produced operation causes obligatory the great difference in the structure of financial statement of these institutions, and direct comparison is impossible.

Nevertheless, within the frameworks of this research the author just demonstrates the difference in the structure of part of assets and in structure of some costs. In general, this comparison cannot be used for analyzing the activities of bank and fintech company. However, it can be used for demonstrating that fintech company can be more efficient due to the peculiar structure of costs and assets when performing the same functions as bank can perform.

The analysis is produced on the basis of financial reports of Starbridge Ltd. for year 2019 (Starbridge Ltd, 2020), and the financial statement of the commercial bank Luminor, operating in Latvia, Lithuania and Estonia (Luminor Bank AS, 2020) for the same year. There were also done the same calculations for year 2018, and the percentage was practically the same as in year 2019, which supported the obtained results. The choice of year, used for analysis, is based on the following: the company appeared only in year 2017, and the very first year of activities cannot be considered as a relevant one. In the second year the company functioned and started some projects, but year 2019 is the period when company uses its capacities in full scope, and continues the growth. The bank "Luminor" also had some structural changes (merge with another bank, change in assets, headquarter, general policy). Therefore, it was decided to use mainly year 2019 for comparison, though, similar analysis was conducted for year 2018. The results for year 2018 were very close to the results of year 2019.

The direct comparison is impossible, since the bank operates in three countries, and produces the full range of banking operations, while Starbridge Ltd. produces very limited number of operations/projects; the fintech company and bank have only few functions which coincide; they also have absolutely different structure of assets, liabilities, incomes.

There is also a certain difficulty in comparison of the structure of assets, which are very specific with the bank. For making comparison more viable, the author has taken only those components of bank assets, which can be compared with the assets of fintech company. As a result, such assets, as balances with central bank and other credit institutions, derivatives, other financial assets, loans to customers to any institutions and some others have been excluded from the analysis, though they are traditional part of assets for any bank and are absolutely necessary for bank analysis.

Such assets as property, plant and equipment, intangible assets, investments in subsidiaries, assets classified as held for sale and other assets were included in analysis, since they can be compared to the structure of assets of fintech company. 


\section{JOURNAL OF TOURISM AND SERVICES}

Issue 23, volume 12, ISSN 1804-5650 (Online)

www.jots.cz

To compare the structure of costs basing on financial statements of fintech company and bank is also very difficult, since these enterprises consider the same types of costs in different points of financial statement. For example, the costs of labor are referred to production costs in case of fintech company, while the bank has a special point "Personnel expenses". Therefore, for comparison there were chosen the positions which mostly correspond to the research purposes. There were taken the parts of financial statement, which reflect the expenditures on labor and on administration, regardless the name of the structural part in the financial statement.

\section{Results}

\subsection{Cost Function for Fin'Tech Company}

Digital banking in Riga is presented by fintech companies, one of which is Starbridge Ltd. The main field of activities of the company is the implementation of innovative projects.

Any innovative projects introduced by fintech company requires the estimation, but this estimation is sometimes quite difficult due to many reasons. One of the reasons for it is the necessity for the company produce several projects simultaneously, and it is not always possible to separate the costs. Another very important thing is the difficulty in estimating the importance of definite type of costs for this or that project. The projects differ in length, in the number of involved staff, in employed equipment, and so on. As a result, the fintech companies often have difficulties in accurate estimating the separate project. Nevertheless, it is very important in each case. The accurate cost benefit analysis of smart solutions is necessary for successful functioning of the fintech company and smart city in general.

There is the accumulation of the main costs and incomes for Starbridge Ltd., based on semistructured interview of company management. It allowed to conduct the cost benefit analysis of the company activities and design the cost function and income function.

The costs are calculated according to the following function (Zhilenkova et al., 2019):

$$
\mathrm{TC}=f(I C, O C, t)
$$

where IC is initial costs of the project within the digital banking; OC is operational costs per year for performing the normal functioning of the project system; $\mathrm{t}$ - time component - planned number of periods of the project functioning.

In its turn, each component of the function can be represented by numerous types of costs.

So, the initial costs are compulsory component of each innovative project. In some cases, this component is so significant that it becomes the most weighted element of the function. The digital banking projects require the initial capital investments as well. Moreover, many costs in the projects, provided by fintech companies in smart city depend on the entire value of the project, since nowadays these companies are very different, and the span of their operations and their turnovers vary significantly.

In case of digital banking, the initial costs include purchase of intellectual capital, software, equipment, labor at the initial stage. There also the costs for creation of the infrastructure and the development of integration procedure of this infrastructure in the structures of smart city, and also other costs.

Therefore, the initial costs can be represented by the following model:

$$
\mathrm{IC}=\mathrm{y}\left(K ; C_{1} ; C_{2} ; C_{3} ; C_{4} ; C_{5} ; C_{6} ; C_{7} ; C_{8}\right)
$$

where $K$ is the value of fintech company project, $C_{1}$ corresponds to the cost of intellectual capital investment, $C_{2}$ is the cost of software, $C_{3}$ is the cost of equipment, $C_{4}$ is the cost of labor at the initial stage, $C_{5}$ is the cost of infrastructure; $C_{6}$ is the cost of development of integration of the infrastructure 


\section{JOURNAL OF TOURISM AND SERVICES}

Issue 23, volume 12, ISSN 1804-5650 (Online)

www.jots.cz

with all involved structures and its upgrading; $C_{7}$ is the cost of insurance. These costs are determined, and some costs which are impossible for selection as independent components, are included in $C_{8}-$ other costs.

The intellectual capital is presented by licenses and permissions; software is presented by special programs used by programmers in the process of creating the soft for digital banking.

The equipment position usually includes the hardware for creating software, and also some office equipment for implementing organizational and monitoring procedures. The company almost does not have the expenses on the hardware, since the programmers are mostly the specialists working distantly using their own hardware. The company operations do not require the daily and consumable equipment. Nevertheless, the company invests significant capital in such assets as servers, which can be in both hardand virtual form. The volume of such investments depends on the number of customers and on the amount of data, which should be kept and processed in the implemented project.

The costs for infrastructure creation are usually covered by the future buyers of the digital banking services - financial institutions; however, it is not correct to exclude them from the general function, since there are cases when the companies cover these costs or part of these costs themselves. In case it happens, the companies also must invest in integration of this infrastructure; certainly, if they use the ready infrastructure, which has already been integrated, they do not have these costs. However, the company integrates the developed product to the existing infrastructure.

The cost of insurance is significant; moreover, it is growing each year. However, it is one of the most important expenditures, since insurance decreases the risks of the company.

The category "other costs" includes the costs which always exist but which are not referred to the above mentioned categories, for example, rent and utility costs, such as telecommunication, internet, electricity.

What is important to emphasize, there is the different status of some costs. For example, costs of infrastructure and infrastructure integration are usually not actual for fintech companies; they prefer to use the infrastructure created by other participants of financial market, while for financial institutions this type of costs is mandatory without any exclusion. As a result, it is necessary to introduce in this function the new component $\%$, which can take values 1 or 0 depending on the existence of this type of costs for fintech company.

The significant share of costs for financial institutions fall for premises which are necessary for implementing the activities of financial institutions, while for fintech companies these costs fall in category "others", since they are so insignificant in the general structure of costs of digital banking products creation that it is even impossible to place them into separate category - small office room compared to substantial premises of the bank and its subsidiaries, for example.

Another important difference in the initial costs of traditional financial institution and fintech company is equipment.

The fintech company is very flexible, and uses the opportunities of distant work for its employees, and in this case they do not invest heavily in equipment for creation of software.

Almost all costs of the banking product produced by fintech company are dependent on the value of the project, implemented by the fintech company. This dependence of each component of the function is introduced by $k$ component, taking value from zero to one. The higher the dependence of each type of costs of the digital banking product on the value of the project, the closer it is to 1 .

The factors of model have the following form:

$C_{1}=\varphi_{1}\left(K ; k_{1}\right)$, where $k_{1} \varepsilon[0 ; 1]$;

$C_{2}=\varphi_{2}\left(K ; k_{2}\right)$, where $k_{2} \varepsilon[0 ; 1]$;

$C_{3}=\varphi_{3}\left(K ; k_{3}\right)$, where $k_{3} \varepsilon[0 ; 1]$;

$C_{4}=\varphi_{4}\left(K ; k_{4}\right)$, where $k_{4} \varepsilon[0 ; 1] ;$

$C_{5}=2,5 \cdot \varphi_{5}\left(K ; k_{5}\right)$, where $k_{5} \varepsilon[0 ; 1]$ and $2_{5} \varepsilon\{0 ; 1\}$;

$C_{6}=z_{6} \cdot \varphi_{6}\left(K ; k_{6}\right)$, where $k_{6} \varepsilon[0 ; 1]$ and $\eta_{6} \varepsilon\{0 ; 1\}$; 


\section{JOURNAL OF TOURISM AND SERVICES}

Issue 23, volume 12, ISSN 1804-5650 (Online)

www.jots.cz

$C_{7}=\varphi_{7}\left(K ; k_{7}\right)$, where $k_{7} \varepsilon[0 ; 1]$;

As a result, the final version of initial costs model of the payment system, represented by fintech company, has the relationships as follows:

$\mathrm{IC}=y\left(K ; \varphi_{1}\left(K ; k_{1}\right) ; \varphi_{2}\left(K ; k_{2}\right) ; \varphi_{3}\left(K ; k_{3}\right) ; \varphi_{4}\left(K ; k_{4}\right) ; 2_{5} \cdot \varphi_{5}\left(K ; k_{5}\right) ; 2_{6} \cdot \varphi_{6}\left(K ; k_{6}\right) ; \varphi_{7}\left(K ; k_{7}\right) ; C_{8}\right)$

$k_{1} \varepsilon[0 ; 1] ; k_{2} \varepsilon[0 ; 1] ; k_{3} \varepsilon[0 ; 1] ; k_{4} \varepsilon[0 ; 1] ; k_{5} \varepsilon[0 ; 1] ; k_{6} \varepsilon[0 ; 1] ; k_{7} \varepsilon[0 ; 1] ;$

$25 \varepsilon\{0 ; 1\} ; 2_{6} \varepsilon\{0 ; 1\}$

The operational costs $\mathrm{OC}$ for payment system include wages and salaries, payment for databases, annual certification, staff training and re-training, R\&D. There are also other costs.

Then, the function of operational costs is as follows:

$\mathrm{OC}=f\left(L_{1} ; L_{2} ; L_{3} ; L_{4} ; L_{5} ; L_{6} ; L_{7}\right)$

where $L_{1}$ is wages and salaries, $L_{2}$ is payment for using the database, $L_{3}$ is the cost of annual certification, $\mathrm{L}_{4}$ is the costs of staff training, $\mathrm{L}_{5}$ is the costs of $\mathrm{R} \& \mathrm{D}$, necessary for digital banking updating, $\mathrm{L}_{6}$ is the alternative costs, and $\mathrm{L}_{7}$ refers to "other costs".

The wages and salaries include the payments to the software developers, software testers, administrative staff. These costs are the most significant ones for the company, since the employees are really highly qualified professionals, and they are very expensive. According to Michael Porter, the only meaningful concept of competitiveness is productivity (Porter, 1990; Porter et al., 2008), which could be provided only by professionals with high qualification. Moreover, it could be noted that these costs are important not only for the company, but also for the entire city, country, region, since they increase the competitiveness capacity (Popova and Petrov, 2019; Aiginger and Firgo, 2017; Thissenet al., 2013). The operation of digital banking requires the database of users, and fintech companies do not create their own databases but traditionally pay for using the existing ones.

The products and operations in the financial markets should fully correspond to the legislation both international and national, and the compliance of the product to the legal acts should be proven. Therefore, the digital banking products must receive the annual certification. The main resource for the fintech company is qualified professionals, which allow the company to be really flexible and to respond very quickly to the market needs, and it is possible only with the participation of staff in training sessions and with own innovative activities. Moreover, the staff, which is not involved in software development, but participate in operation with the developed product, also should have training. The company is involved in teaching the staff of financial institutions working with the product. This position can be referred to alternative, or opportunity costs - the company does not pay for these trainings, but time and labour force are involved. Another type of alternative costs is training of the applicants for the position in the company. One more type - internal experience exchange. Since these costs are determined only via time and labour spent, they are represented with coefficient $n$ demonstrating the dependence on wages and salaries and coefficient $m$ representing the time. Other costs include costs of telecommunication, internet, electricity, etc.

Then, the function of the alternative costs can be represented as follows:

$L_{6}=a\left(L_{1} ; n ; m\right)$

Therefore, the model of operational costs has the following view:

$O C=f\left(L_{1} ; L_{2} ; L_{3} ; L_{4} ; L_{5} ; a\left(L_{1} ; n ; m\right) ; L_{7}\right)$

As it can be seen, the structure of costs of fintech companies is quite specific, and this fact determines some advantages of fintech companies in the digital market of smart city, and also some limitations for its activities.

\subsection{Structure of Income of Fin Tech Company and Income Function}

The revenue of any fintech company is based on its ability to adjust to the changeable situation in the financial markets quickly and without serious structural shifts. The flexibility and readiness to react immediately to any demands and needs of the customers make these companies unique players in these 


\section{JOURNAL OF TOURISM AND SERVICES}

Issue 23, volume 12, ISSN 1804-5650 (Online)

www.jots.cz

markets, and create additional benefits for fintech company, and also contribute to the additional challenges for them.

The income from selling the specific product of digital banking consists of many components. Fintech company has income from design, integration and servicing the software for digital banking, it provides support and consultations for employees and operators, working with customers. One of the specific functions of fintech company is servicing the clients of company's customers at a contact centre, and it also provides a certain income. The income is determined by the set of services chosen by the customer. For example, company can sell the licenses for the designed products, and further the customer has option - to deal with all the issues on maintenance and servicing of the product independently or to use the fintech company support. The company can integrate the product, serve it, provide the modifications specific for the customer of the software. Sometimes company can have income which is not standard for the company, and such income is referred as "Other Incomes"

Therefore, the basic function of income of fintech company can be as follows:

$I n c=\lambda\left(V ; \mathrm{R}_{1} ; \mathrm{R}_{2} ; \mathrm{R}_{3} ; \mathrm{R}_{4} ; \mathrm{R}_{5} ; \mathrm{R}_{6} ; \mathrm{R}_{7}\right)$

where

$\mathrm{V}-$ is the value of the produced project

$\mathrm{R}_{1}$ - income from product designing and selling the license

$\mathrm{R}_{2}$ - income from product integration

$\mathrm{R}_{3}$ - income from servicing the product

$\mathrm{R}_{4}$ - income from product upgrading and modifying for specific needs of the customer

$\mathrm{R}_{5}$ - income from consulting the employees and operators, working with customers

$\mathrm{R}_{6}$ - income from servicing the clients of fintech customers at a contact center

$\mathrm{R}_{7}-$ other incomes.

As it has been mentioned above, for each project or client the set of provided services is very specific, and therefore, each of the described sources of income can exist or not, depending on the specific needs of the customer. Therefore, it is necessary to introduce the component $x$, which can take the value of 0 or 1 , depending on fact of being actual for this specific project. Another important factor is time of producing service, since the company can provide each particular type of servicing for specific time, which is important for the income of the company, and this time can be different for each component of income. Therefore, the component $t$ is introduced. Then, there considered the dependence of income on the entire value of the project $V$, as it was in case with costs function. The component $v$, showing the dependence of the factor on the value of the entire project $V$, can take values from 0 to 1 .

The component $\mathrm{R}_{7}$ - other incomes - is supposed as independent from time and relation with the value of the project.

As a result, there the components of the function are as follows:

$\mathrm{R}_{1}=g\left(V ; v_{1} ; t_{1}\right)$, where $v_{1} \varepsilon[0 ; 1]$ and $x_{1} \varepsilon\{0 ; 1\}$

$\mathrm{R}_{2}=g\left(V ; v_{2} ; t_{2}\right)$, where $v_{2} \varepsilon[0 ; 1]$ and $x_{2} \varepsilon\{0 ; 1\}$

$\mathrm{R}_{3}=g\left(V ; v_{3} ; t_{3}\right)$, where $v_{3} \varepsilon[0 ; 1]$ and $x_{3} \varepsilon\{0 ; 1\}$

$\mathrm{R}_{4}=g\left(V ; v_{4} ; t_{4}\right)$, where $v_{4} \varepsilon[0 ; 1]$ and $x_{4} \varepsilon\{0 ; 1\}$

$\mathrm{R}_{5}=g\left(V ; v_{5} ; t_{5}\right)$, where $v_{5} \varepsilon[0 ; 1]$ and $x_{5} \varepsilon\{0 ; 1\}$

$\mathrm{R}_{6}=g\left(V ; v_{6} ; t_{6}\right)$, where $v_{6} \varepsilon[0 ; 1]$ and $x_{6} \varepsilon\{0 ; 1\}$

The final version of the income function is as follows:

Inc $=\lambda\left(V ; x_{1} \cdot g_{1}\left(V ; v_{1}\right) ; x_{2} \cdot g_{2}\left(V ; v_{2}\right) ; x_{3} \cdot g_{3}\left(V ; v_{3}\right) ; x_{4} \cdot g_{4}\left(V ; v_{4}\right) ; x_{5} \cdot g_{5}\left(V ; v_{5}\right) ; x_{6} \cdot g_{6}\left(V ; v_{6}\right) ; R_{7}\right)$, $v_{1} \varepsilon[0 ; 1] ; v_{2} \varepsilon[0 ; 1] ; v_{3} \varepsilon[0 ; 1] ; v_{4} \varepsilon[0 ; 1] ; v_{5} \varepsilon[0 ; 1] ; v_{6} \varepsilon[0 ; 1] ;$

$x_{1} \varepsilon\{0 ; 1\} ; x_{2} \varepsilon\{0 ; 1\} ; x_{3} \varepsilon\{0 ; 1\} ; x_{4} \varepsilon\{0 ; 1\} ; x_{5} \varepsilon\{0 ; 1\} ; x_{6} \varepsilon\{0 ; 1\}$

Therefore, function of fintech company revenue received from the projects has very complex structure.

However, these costs function and income function should be considered by the fintech companies in the process of planning their activities. 


\section{JOURNAL OF TOURISM AND SERVICES}

Issue 23, volume 12, ISSN 1804-5650 (Online)

www.jots.cz

The elaborated functions were used for estimating one of the project, implemented by the company. The project is still in the process of implementation, and the data were taken for 1 year of project operating. The Benefit/Cost Ratio of the project for the first year is 1.258 , which is very good indicator, and if to consider that the project is not finished, and each period the difference between costs and revenues increases, the project will be more and more beneficial for the company. The Costs and Revenues of the company are shown in diagram in Graph 2.

\section{Graph 2. Costs and Revenues of the project implemented by fintech company}

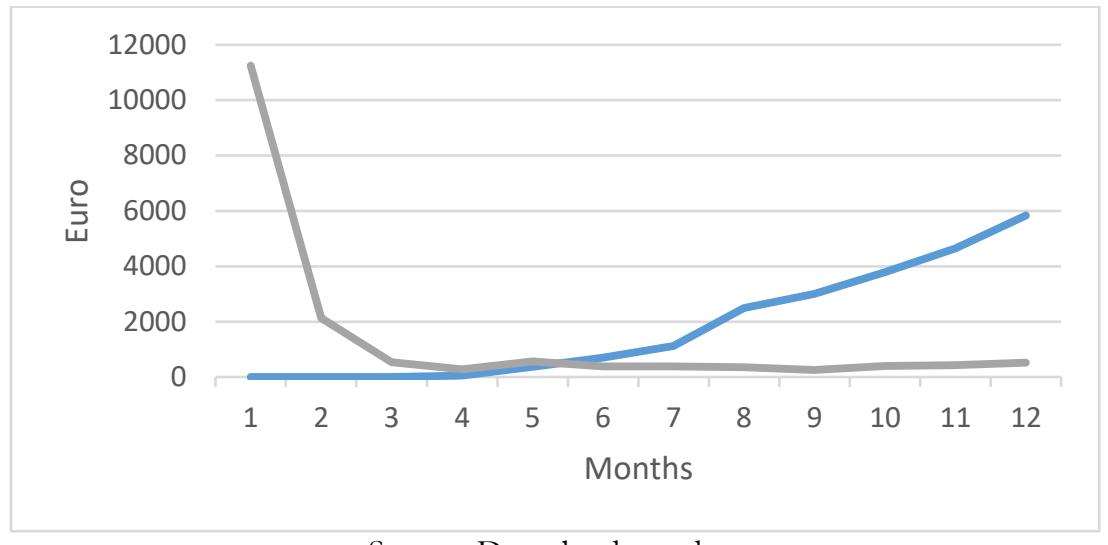

Source: Done by the author

As it is seen on the diagram, the costs are very high in the first period, since they include the initial costs (software, equipment, labor and insurance $-C_{2}, C_{3}, C_{4}$ and $C_{7}$ from function, correspondently). The operational costs are comparatively low, starting from period 3 they correspond to $L_{1}$ of the function, but it is expected in the beginning of year 2 the operational costs will increase, since other costs are expected. However, the revenue from the project starts growing, and by the end of the year it is significantly higher compared to the costs.

\subsection{Comparison of Some Indicators of Fintech Company and Traditional Bank}

To demonstrate the success of fintech companies in smart city and to prove that the share of digital banking services produced by these companies have the potential to grow, there produced the comparison of fintech company and traditional bank in some positions.

The analysis is complicated by the fact of different structure of financial reports of fintech company and the commercial bank.

Nevertheless, within the frameworks of this research the author uses several parts of the financial statements adjusted to the needs of the study, and demonstrates the difference in the structure of some costs, which can serve as an evidence of efficiency of fintech company. The fintech company be more efficient when performing the same functions as bank can perform.

The structure of assets is also different; as a result, the viable comparison was also possible only after certain adjustments, described in section Methods. certain difficulty in comparison the structure of assets, which are very specific with the bank.

The following results were obtained (see Graph 3).

The result is quite expectable, since the expenditures of Fintech company and bank for intangible assets are very important, they predetermine what activities and in what spheres the company and the bank can implement. Though they are sunk costs for the them, fintech company is ready to buy intangible assets, which allow the company to increase the range of activities, which predetermines the possibility of existence of this type of companies. Banks are also dependent on the intangible assets, which are the 


\section{JOURNAL OF TOURISM AND SERVICES}

Issue 23, volume 12, ISSN 1804-5650 (Online)

www.jots.cz

part of necessary set of assets and allow the bank to operate on the market. The difference is not really significant, both institutions depend on intangible assets.

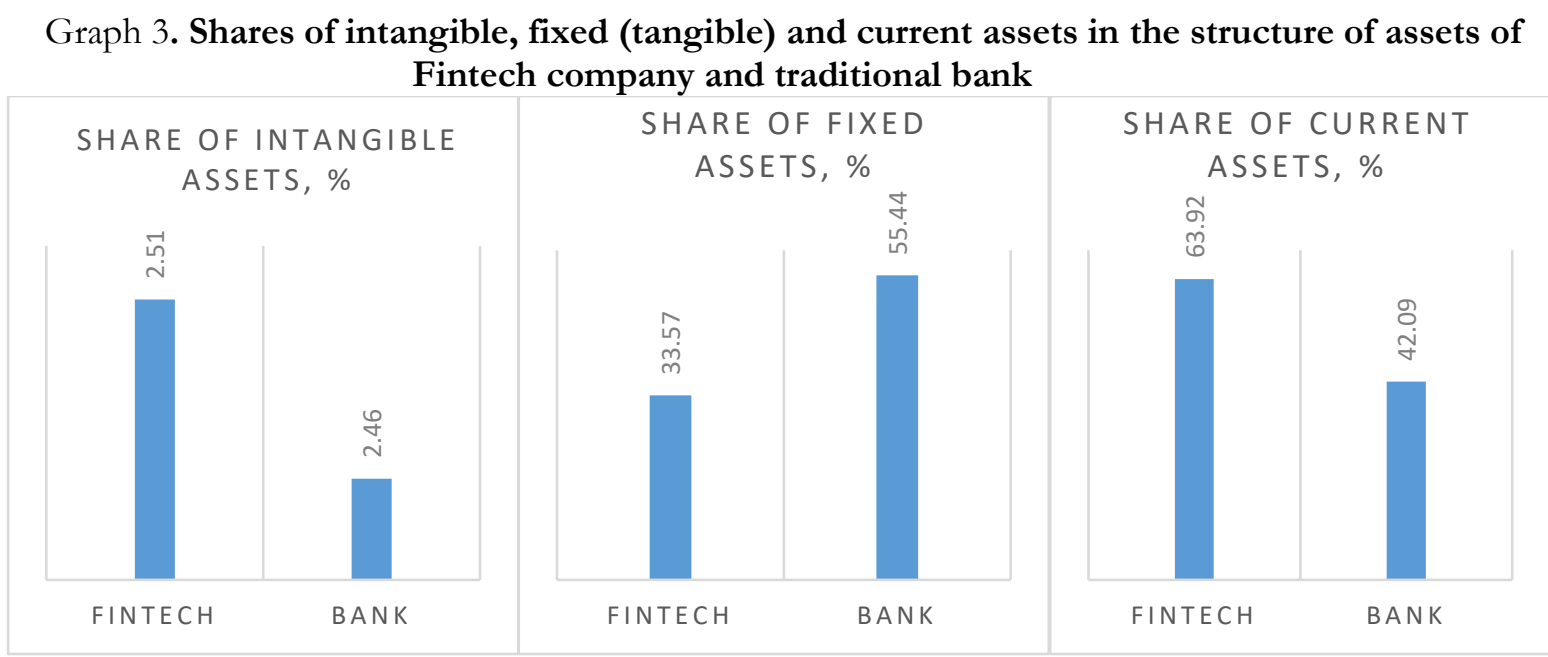

Source: Done by the author on the basis of the financial statements (Starbridge Ltd., 2020; Luminor Bank AS, 2020)

The situation with fixed tangible and current assets is absolutely different. The fixed assets create the physical basis for the operations. As it is demonstrated in the diagram in Fig. 3, the share of fixed tangible assets within the fintech is significantly smaller compared to bank. It makes the fintech company more flexible, decreases its costs, allows the company to follow very quickly all the tendencies in the market. However, the bank can operate with more comprehensive services, but it is less flexible. Correspondently, the share of current assets (for bank it is assets presupposed for sale) is significantly higher with fintech company; the most of its assets can be turned into money form during one production cycle. For bank this indicator is significantly lower.

The comparison of the structure of costs of fintech company and bank is also impossible without adjustments, since these enterprises consider the same types of costs in different points of financial statement. Therefore, for comparison there were chosen the positions which mostly correspond to the research purposes.

The diagrams in Graph 4 demonstrate these positions for fintech company and bank.

In general, the biggest share of costs of fintech company is referred to the personnel costs, which is logical, since the people working for such company are highly qualified professionals, and the company gains only in case of employing such specialists. Banks deal not only with technological products, and as a result the share of expenditures on personnel is significantly lower compared to fintech. The situation with administrative costs is opposite - for fintech company the expenditures on administration are lower compared to bank, but the difference is not so big as in situation with personnel. However, as the analysis demonstrates, the fintech company spends almost $66 \%$ on personnel and administration, while for bank this value is almost $55 \%$.

Therefore, the analysis of financial statement supports the idea that the fintech company invests less in own fixed assets and prefers using the fixed assets created by other companies (for example, infrastructure). This fact allows the company to be more flexible and responsive to new trends in the market. Since the biggest share of its assets is current assets, the company can change the direction of operations quite quickly. It gives the company the necessary flexibility and possibility to adjust to the new requirements rather easily. The process of administration for fintech company is also cheaper compared to bank which allows setting more attractive prices for the products, and creates the incentives for extending the range of offered products. The high expenses for staff demonstrate the investment in the 


\section{JOURNAL OF TOURISM AND SERVICES}

Issue 23, volume 12, ISSN 1804-5650 (Online)

www.jots.cz

most valuable resource which is less subjected to depreciation compared to classical capital, which is capable of quick changing and adjusting to new requirements; this is the basis of fintech company ability to correspond perfectly to the changing world.

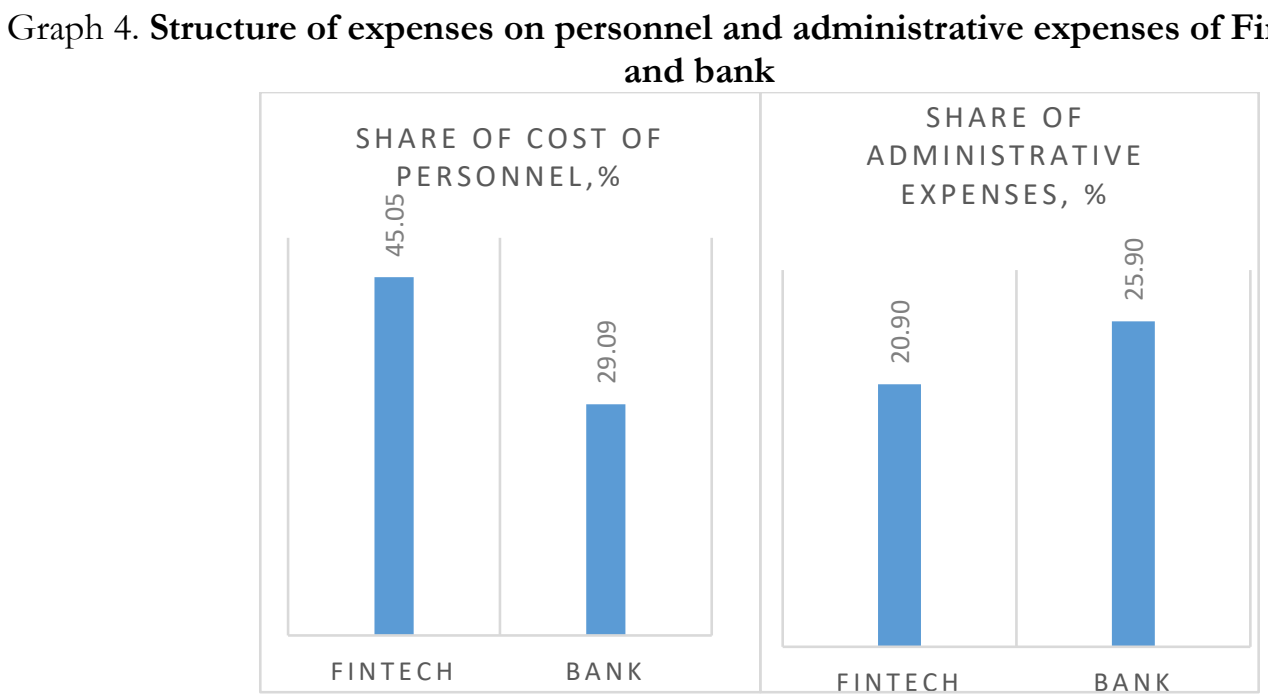

Source: Done by the author on the basis of financial statements (Starbridge Ltd., 2020; Luminor Bank AS, 2020)

\section{Discussion}

The research reveals the economic substantiation of the activities of fintech company producing digital banking services within smart city. The interest towards smart city is growing together with the increased rate of urbanization. The creation of convenient environment for people is closely connected with implementation of technological innovations. Many of them have appeared and continue appearing in the financial market, and for many services the fintech companies become a great alternative for conventional banks, since their services are quick, convenient and cheap.

There are many researches devoted to the technological part of activities of fintech companies, there are also studies of social impact of these companies and the level of customers' satisfaction. There are researches, which emphasize that the services of fintech companies have lower costs compared to the traditional institutions providing the similar services. However, these studies do not focus on the source of this decrease in costs. Nevertheless, it seems to be very important to determine the types of costs and incomes these companies have, and to find out what is the main difference in costs structure between the traditional bank and fintech company. There were developed the functions of costs and revenues for the company, and shown the specificity of these costs and revenues and difference in costs structure between fintech and bank. They can be considered by researchers for substantiation of the financial solutions within fintech companies.

The comparison of structure of assets and costs of fintech and bank permit to conclude, that the difference in intangible assets is not really significant, but fintech spends a bit bigger share for these assets: $2.51 \%$ against $2.46 \%$. The share of fixed assets differs substantially: $33.57 \%$ for fintech and $55.44 \%$ for bank, which can support the idea that fintech can supply cheaper services due to low fixed costs; it is also possible because fintech uses not only company's capacities, but also the fixed assets of banks for providing the services; it creates an advantage for this company. The fintech has $63.92 \%$ of current assets against $42.09 \%$ for the bank. The assets of fintech company are more mobile, making the company more flexible and allowing it to follow the latest trends. Then, fintech costs for personnel and for administration are $45.05 \%$ and $20.90 \%$ correspondently, while for bank they are $29.09 \%$ and $25.90 \%$ relatively. This fact 


\section{JOURNAL OF TOURISM AND SERVICES}

Issue 23, volume 12, ISSN 1804-5650 (Online)

www.jots.cz

also demonstrates, that fintech is ready to pay to people more for being flexible and ready to follow the innovations, and the costs of administration are significantly lower, while for bank the difference between these costs is not so great, just 4\%, making bank less flexible. The calculated Benefit/Cost ratio just exemplifies the efficiency of the projects, implemented by fintech company.

These results can be used in other researches, requiring the economic substantiation of the activities of fintech companies. The study demonstrates the source of decreased costs. The entrepreneurs, working in the area of digital banking, can use the developed functions for further decrease in costs and increase in income, making the company more competitive. It can be very promising, since the fintech companies are taking more and more strong position not only in smart city, but also in global operations, and comprehending the source for costs decrease is important for them.

The research has certain limitations, mostly based on the fact that the direct comparison of assets of company and bank is impossible, and there were presented the certain adjustments before comparison.

\section{Conclusions}

The set problem assumes that the unlimited growth of the urban population results in the necessity to organize the urban environment in the way when the city receives the possibility of living in a smart environment. There exist a great number of smart solutions for improving urban life in a smart city. All of them are connected with financial operations at least at a very basic level. Therefore, providing financial services has become one of the most urgent and necessary functions of smart cities.

Nowadays, a great role in the implementation of financial services belongs to fintech companies. The researches in the area consider mostly the technological issues or social benefits and consumer satisfaction with the services of fintech companies. However, these companies have very peculiar structure of their costs and revenues, and economic substantiation of the fintech company is very important. Special attention in this research is paid to elaborating the cost and income functions of the fintech company. The Benefit/Cost ratio of one of the projects implemented by the fintech company is calculated based on the presented income and cost functions; its value is 1.258 , which is a very good indicator.

The research considers and demonstrates the source of efficiency of fintech companies in comparison with conventional banks. So, the share of intangible assets for fintech companies is $2.51 \%$, and for a bank, this indicator is $2.46 \%$. The difference is not very significant, but if to compare the fixed assets, the difference is more substantial: $33.57 \%$ for fintech and $55.44 \%$ for a bank; the current assets demonstrate a different situation $-63.92 \%$ for fintech, and $42.09 \%$ for the bank. The costs for personnel and administrative costs are distributed as follows: for personnel $-45.05 \%$ for fintech and $29.09 \%$ for a bank, while for administrative purposes $-20.90 \%$ for fintech and $25.90 \%$ for bank. This part of research is rather conditional since it is based on the analysis of financial statements of these two types of organizations, and they are structured absolutely differently. The way of using these statements is described in the section "Methodology"; nevertheless, it can be supposed as a limitation of the research.

The author believes that this study allows decreasing the lacuna existing in economic and financial substantiations of smart solutions in smart cities.

\section{Acknowledgments}

This work was financially supported by the specific support objective activity, Project id. N. 1.1.1.2/16/I/001) of the Republic of Latvia, funded by the European Regional Development Fund. Research project No.1.1.1.2/VIAA/3/19/458 «Development of Model of Smart Economy in Smart City». 


\section{JOURNAL OF TOURISM AND SERVICES}

Issue 23, volume 12, ISSN 1804-5650 (Online)

www.jots.cz

\section{References}

1. Abraham, F., Schmukler, S. L., \& Tessada, J. (2019). Robo-advisors: Investing through machines. World Bank Research and Policy Briefs, (134881).

2. Abrol, S. (2016). Role of Trust and Service Quality in E-Banking. International Journal of Banking, Risk and Insurance, 4(1), 1.

3. Agarwal, S., Lucca, D., Seru, A., \& Trebbi, F. (2014). Inconsistent regulators: Evidence from banking. The Quarterly Journal of Economics, 129(2), 889-938.

4. Aguirre, S., \& Rodriguez, A. (2017). Automation of a business process using robotic process automation (RPA): A case study. In Workshop on engineering applications (pp. 65-71). Springer, Cham.

5. Aiginger, K., Firgo M. (2017). Regional competitiveness: connecting an old concept with new goals. Handbook of Regions and Competitiveness, 155-191. doi:10.4337/9781783475018.00013

6. Alalwan, A., Dwivedi, Y. K. \& Rana, N. P. (2017). Factors influencing adoption of mobile banking by Jordanian bank customers: Extending UTAUT2 with trust, International Journal of Information Management, vol. 37, no. 3, pp. 99-110, doi: https://doi.org/10.1016/j.ijinfomgt.2017.01.002

7. Allen, F., Gu, X., \& Jagtiani, J. (2020). A survey of fintech research and policy discussion. IMF e-Library. https://www.elibrary.imf.org/view/journals/001/2021/105/article-A001-en.xml

8. Al-Saedi, K., Al-Emran, M., Abusham, E., \& El Rahman, S. A. (2019, February). Mobile payment adoption: a systematic review of the UTAUT model. In 2019 International Conference on Fourth Industrial Revolution (ICFIR) (pp. 1-5). IEEE.

9. Anthopoulos, L., Janssen, M., \& Weerakkody, V. (2019). A Unified Smart City Model (USCM) for smart city conceptualization and benchmarking. Smart cities and smart spaces: Concepts, methodologies, tools, and applications, 247-264..

10. Ardito, L., Ferraris, A., Petruzzelli, A. M., Bresciani, S., \& Del Giudice, M. (2019). The role of universities in the knowledge management of smart city projects. Technological Forecasting and Social Change, 142, 312-321.

11. Asif, Ch., Flötotto, M., Olanrewaju, T., Sofo, G. (2020). Detour: An altered path to profit for European fintechs. Digital McKinsey. McKinsey \& Company

12. Báeza, A. \& Herrerob, L.C. (2012). Using contingent valuation and cost-benefit analysis to design a policy for restoring cultural heritage, Journal of Cultural Heritage 13(3), 235-245. http://dx.doi.org/10.1016/j.culher.2010.12.005

13. Baker, M., \& Wurgler, J. (2015). Do strict capital requirements raise the cost of capital? Bank regulation, capital structure, and the low-risk anomaly. American Economic Review, 105(5), 315-20.

14. Bansal, S., Bruno, Ph., Hou, G., Istace, F., Niederkorn, M. (2015). How the payments industry is being disrupted. Digital McKinsey. McKinsey \& Company. https://www.mckinsey.com/industries/financial-services/our-insights/how-the-paymentsindustry-is-being-disrupted

15. Barkhordari, M., Nourollah, Z., Mashayekhi, H., Mashayekhi, Y., \& Ahangar, M. S. (2017). Factors influencing adoption of e-payment systems: an empirical study on Iranian customers. Information systems and e-business management, 15(1), 89-116. https://doi.org/10.1007/s10257-0160311-1

16. Bataev, A. V., Dedyukhina, N., \& Nasrutdinov, M. N. (2020, February). Innovations in the financial sphere: Performance evaluation of introducing service robots with artificial intelligence. In 2020 9th International Conference on Industrial Technology and Management (ICITM) (pp. 256-260). IEEE.

17. Buchak, G., Matvos, G., Piskorski, T., \& Seru, A. (2018). Fintech, regulatory arbitrage, and the rise of shadow banks. Journal of Financial Economics, 130(3), 453-483. 


\section{JOURNAL OF TOURISM AND SERVICES}

Issue 23, volume 12, ISSN 1804-5650 (Online)

www.jots.cz

18. Caballero-Morales, S.O., Cordero-Guridi, J.J., Alvarez-Tamayo, R.I., \& Cuautle-Gutiérrez, L. (2020). Education 4.0 to Support Entrepreneurship, Social Development and Education in Emerging Economies. International Journal of Entrepreneurial Knowledge, 8(2), 89-100. doi: 10.37335/ijek.v8i2.119

19. Civelek, M., Ključnikov, A., Krajč́k, V., \& Žufan, J. (2019). The Importance of Discount Rate and Trustfulness of A Local Currency for the Development of Local Tourism: Journal of Tourism and Services, 10 (19): 77-92. https://doi. org/10.29036/jots. v10i19. 117.

20. Civelek, M., Formánek, I., Nétek, V., \& Paták, M. R. (2020a). International Variations In FirmLevel Strategic Entrepreneurial Orientation Of Smes. Scientific Papers of the University of Pardubice. Series D, Faculty of Economics \& Administration, 28(1), 43-54.

21. Civelek, M., Gajdka, K., Světlík, J., \& Vavrečka, V. (2020b). Differences in the usage of online marketing and social media tools: evidence from Czech, Slovakian and Hungarian SMEs. Equilibrium. Quarterly Journal of Economics and Economic Policy, 15(3), 537-563. doi: 10.24136/eq.2020.024

22. Civelek, M., Ključnikov, A., Fialova, V., Folvarčná, A., \& Stoch, M. (2021a). How innovativeness of family-owned SMEs differ depending on their characteristics? Equilibrium. Quarterly Journal of Economics and Economic Policy, 16(2), 413-428. doi: 10.24136/eq.2021.015

23. Civelek, M., Ključnikov, A., Kloudová, J., \& Vozňáková, I. (2021b). Digital Local Currencies as an Alternative Digital Payment Method for Businesses to Overcome Problems of Covid-19 Pandemic. Polish Journal of Management Studies, 23(2), 57-71. DOI: 10.17512/pjms.2021.23.2.04

24. Cortis, D., Debattista, J., Debono, J., \& Farrell, M. (2019). InsurTech. In Disrupting finance (pp. 71-84). Palgrave Pivot, Cham.

25. Customer Loyalty in Retail Banking: Global Edition, December, (2014) http://www.bain.com/publications/articles/customer-loyalty-in-retail-banking-2014global.aspx

26. Darolles, S. (2016). The rise of fintechs and their regulation. Financial Stability Review, (20), 85-92.

27. David, R., Ngulube, P., \& Dube, A. (2013). A cost-benefit analysis of document management strategies used at a financial institution in Zimbabwe: A case study. SA Journal of Information Management, 15(2). doi:10.4102/sajim.v15i2.540

28. Dhar, V. (2016). When to trust robots with decisions, and when not to. Harvard Business Review, 17.

29. Dranev, Y., Frolova, K., \& Ochirova, E. (2019). The impact of fintech M\&A on stock returns. Research in International Business and Finance, 48, 353-364.

30. Etezadzadeh, C. (2016). Smart City - Future City? Essentials. Smart city 2.0 as a livable city and future market. Springer.doi:10.1007/978-3-658-11017-8

31. European Commission. (2014). What are Smart Cities? Cities and Urban Development. Smart Cities. https://ec.europa.eu/info/eu-regional-and-urban-development/topics/cities-and-urbandevelopment/city-initiatives/smart-cities_en

32. Findexable Limited. (2020). The Global Fintech Index 2020. City Rankings Report. Findexable Limited\& The Global Fintech Index. https://findexable.com/wpcontent/uploads/2019/12/Findexable_Global-Fintech-Rankings-2020exSFA.pdf

33. Francisco, L. C., Francisco, M. L., \& Juan, S. F. (2015). Payment systems in new electronic environments: consumer behavior in payment systems via SMS. International Journal of Information Technology \& Decision Making, 14(02), 421-449.

34. Gârleanu, N., \& Pedersen, L. H. (2018). Efficiently inefficient markets for assets and asset management. The Journal of Finance, 73(4), 1663-1712.

35. Granja, J., Matvos, G., \& Seru, A. (2017). Selling failed banks. The Journal of Finance, 72(4), 1723 1784. 


\section{JOURNAL OF TOURISM AND SERVICES}

Issue 23, volume 12, ISSN 1804-5650 (Online)

www.jots.cz

36. IMD World Competitiveness Center. Smart City Index 2020. SCI Report. Institute for Management Development (IMD), in collaboration with Singapore University for Technology and Design (SUTD)

37. International Records Management Trust (IRMT), 2006, Project management guideline: Appendix D - A cost/benefit analysis guideline, IRMT, London.

38. Kelemen, M.; Polishchuk, V.; Gavurová, B.; Rozenberg, R.; Bartok, J.; Gaál, L.; Gera, M.; Kelemen, M., Jr. (2021). Model of Evaluation and Selection of Expert Group Members for Smart Cities, Green Transportation and Mobility: From Safe Times to Pandemic Times. Mathematics, 9 , 1287. https:// doi.org/10.3390/math9111287

39. Klevets, A. (2021). What is FinTech? Financial "Academy Active". https://finacademy.net/materials/article/fintech

40. Ključnikov, A., Mehmet Civelek, Petr Čech, \& Jitka Kloudová,. (2019). Entrepreneurial orientation of SMEs' executives in the comparative perspective for Czechia and Turkey. Oeconomia Copernicana, 10(4), 773-795. doi: 10.24136/oc.2019.035

41. Ključnikov, A., Civelek, M., Polách, J., Mikoláš, Z., \& Banot, M. (2020a). How do security and benefits instill trustworthiness of a digital local currency? Oeconomia Copernicana, 11(3), 433-465. doi: $10.24136 /$ oc. 2020.018

42. Ključnikov, A., Civelek, M., Vozňáková, I., \& Krajč́́k, V. (2020b). Can discounts expand local and digital currency awareness of individuals depending on their characteristics? Oeconomia Copernicana, 11(2), 239-266. doi: 10.24136/oc.2020.010

43. Ključnikov, A., Civelek, M., Fialova, V., \& Folvarčná, A. (2021). Organizational, local, and global innovativeness of family-owned SMEs depending on firm-individual level characteristics: evidence from the Czech Republic. Equilibrium. Quarterly Journal of Economics and Economic Policy, 16(1), 169-184. doi: 10.24136/eq.2021.00

44. Koopmans, C. C., \& Mouter, N. (2020). Cost-benefit analysis. Standard Transport Appraisal Methods. Advances in Transport Policy and Planning, 6, 1-42.

45. Kozak, S., \& Golnik, B. (2020). Migration of the banking sector to digital banking in Poland. Economic and Regional Studies (Studia Ekonomic:ne i Regionalne), 13(673-2020-1739), 284294.

46. Kumar, T. V., \& Dahiya, B. (2017). Smart economy in smart cities. In Smart economy in smart cities (pp. 3-76). Springer, Singapore.

47. Lai C.S., Jia Y., Dong Z., Wang D., Tao Y., Lai Q.H., Wong R.T., Zobaa A.F., Wu R., Lai L.L. (2020). A review of technical standards for smart cities. Clean Technologies, 2(3), 290-310

48. Luminor Bank AS. (2020). Annual Financial Statement for year 2019. Lursoft.lv Databases. https://www.lursoft.lv/?l=en

49. Makarchenko, M., Nerkararian, S., \& Shmeleva, I. A. (2016, June). How traditional banks should work in smart city. In International Conference on Digital Transformation and Global Society (pp. 123134). Springer, Cham.

50. Malaika, M. (2021). Central Bank Risk Management, Fintech, and Cybersecurity. IMF Working Papers, 2021(105).

51. Marano, P. (2019). Navigating InsurTech: The digital intermediaries of insurance products and customer protection in the EU. Maastricht Journal of European and Comparative Law, 26(2), 294315.

52. McAndrews, J. J. (2020). The case for cash. Latin American Journal of Central Banking, 1(1-4), 100004..

53. Medina-Borja, A. (2017). Smart human-centered service systems of the future. Center for Research and Development Strategy, Science and Technology Agency, Future Services \& Societal Systems in Society, 5, 2017 


\section{JOURNAL OF TOURISM AND SERVICES}

Issue 23, volume 12, ISSN 1804-5650 (Online)

www.jots.cz

54. Mehrad, D., \& Mohammadi, S. (2017). Word of Mouth impact on the adoption of mobile banking in Iran. Telematics and Informatics, 34(7), 1351-1363.

55. Mouter, N. (2018). A critical assessment of discounting policies for transport Cost-Benefit Analysis in five European practices. European Journal of Transport and Infrastructure Research, 18(4).

56. Ngulube, P. (2011). Cost analysis and the effective management of records throughout their life cycle, South Africa Journal 44, 1-21.

57. Ozili, P. K. (2018). Impact of digital finance on financial inclusion and stability. Borsa Istanbul Review, 18(4), 329-340. https://doi.org/10.1016/j.bir.2017.12.003.

58. Petralia, K., Philippon, T., Rice, T. N., \& Véron, N. (2019). Banking Disrupted?: Financial Intermediation in an Era of Transformational Technology. ICMB International Center for Monetary and Banking Studies.

59. Philippon, T. (2015). Has the US finance industry become less efficient? On the theory and measurement of financial intermediation. American Economic Review, 105(4), 1408-38.

60. Philippon, T. (2016). The fintech opportunity. Work Paper (No. w22476). National Bureau of Economic Research.

61. Popova, Y. (2020). Economic or financial substantiation for smart city solutions: a literature study. Economic Annals-XXI, 183(5-6), 125-133. doi: https://doi.org/10.21003/ea.V183-12

62. Popova, Y., \& Petrov, I. (2019). Impact of the Human Capital Factors on the Country Competitiveness. In International Conference on Reliability and Statistics in Transportation and Communication (pp. 662-671). Springer, Cham.

63. Porter, M. (1990). The Competitive Advantage of Nations. In: Harvard Business Review, http://hbr.org/1990/03/the-competitive-advantage-of-nations/ar/1.

64. Porter, M., Delgado, M., Ketels, C., Stern, S. (2008). Moving to a New Global Competitiveness Index. The Global Competitiveness Report 2008-2009, 43-63. World Economic Forum, Geneva, Switzerland.

65. Rogoff, K., \& Rogoff, K. S. (2017). The curse of cash. Princeton University Press.

66. Rubio, J., Barucca, P., Gage, G., Arroyo, J., \& Morales-Resendiz, R. (2020). Classifying payment patterns with artificial neural networks: An autoencoder approach. Latin American Journal of Central Banking, 1(1-4), 100013..

67. Salloum, S. A., Al-Emran, M., Khalaf, R., Habes, M., \& Shaalan, K. (2019). An Innovative Study of E-Payment Systems Adoption in Higher Education: Theoretical Constructs and Empirical Analysis. International Journal of Interactive Mobile Technologies, 13(6).

68. Serrano, W. (2018). Digital systems in smart city and infrastructure: Digital as a service. Smart cities, 1(1), 134-154.

69. Starbridge Ltd. (2020). Annual Financial Statement for year 2019. Lursoft.lv Databases. https://www.lursoft.lv/?l=en

70. Stoeckli, E., Dremel, C., \& Uebernickel, F. (2018). Exploring characteristics and transformational capabilities of InsurTech innovations to understand insurance value creation in a digital world. Electronic markets, 28(3), 287-305.

71. Thissen, M., Van Oort, F., Diodato, D., \& Ruijs, A. (2013). Regional competitiveness and smart specialization in Europe: Place-based development in international economic networks. Edward Elgar Publishing..

72. Varga, D. (2017). Fintech, the new era of financial services. Vezetéstudominy-Budapest. Management Review, 48(11), 22-32.

73. Wataya, E., \& Shaw, R. (2019). Measuring the value and the role of soft assets in smart city development. Cities, 94, 106-115.

74. Zagulova D., Popova Y. (2021). Strategies of the universities in managing the intellectual capital within the smart city concept: Narrative literature review. Strategic Decisions and Risk Management, 12(1), 34-49. DOI: 10.17747/2618-947X-2021-1-34-49. 
75. Zheng, Z., Xie, S., Dai, H. N., Chen, W., Chen, X., Weng, J., \& Imran, M. (2020). An overview on smart contracts: Challenges, advances and platforms. Future Generation Computer Systems, 105, 475-491.

76. Zhilenkova, E., Budanova, M., Bulkhov, N., \& Rodionov, D. (2019). Reproduction of intellectual capital in innovative-digital economy environment. In IOP Conference Series: Materials Science and Engineering, Vol. 497, No.1, 2019, p. 012065, IOP Publishing

\section{Brief description of Author:}

\section{Ms. Yelena Popova,}

ORCID ID: https://orcid.org/0000-0002-8034-5935

Email: yelenagp@gmail.com

Transport and Telecommication Institute, Faculty of Economics and Management, Riga, Latvia.

Doctor of Economics, Professor

The main fields of research: Smart Economy; Sustainability; Environmental Economy; Human Capital. 